\title{
Front Matter: Volume 10115
}

, "Front Matter: Volume 10115," Proc. SPIE 10115, Advanced Fabrication Technologies for Micro/Nano Optics and Photonics X, 1011501 (5 May 2017); doi: $10.1117 / 12.2276160$

SPIE. Event: SPIE OPTO, 2017, San Francisco, California, United States 


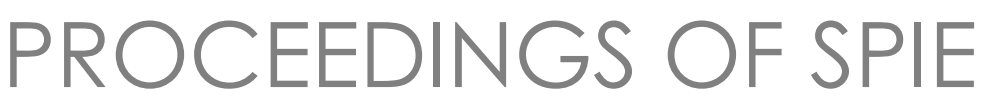

\title{
Advanced Fabrication Technologies for Micro/Nano Optics and Photonics $X$
}

\author{
Georg von Freymann \\ Winston V. Schoenfeld \\ Raymond C. Rumpf \\ Editors
}

29 January-1 February 2017

San Francisco, California, United States

Cosponsored by

Nanoscribe GmbH (Germany)

Sponsored and Published by

SPIE 
The papers in this volume were part of the technical conference cited on the cover and title page. Papers were selected and subject to review by the editors and conference program committee. Some conference presentations may not be available for publication. Additional papers and presentation recordings may be available online in the SPIE Digital Library at SPIEDigitallibrary.org.

The papers reflect the work and thoughts of the authors and are published herein as submitted. The publisher is not responsible for the validity of the information or for any outcomes resulting from reliance thereon.

Please use the following format to cite material from these proceedings:

Author(s), "Title of Paper," in Advanced Fabrication Technologies for Micro/Nano Optics and Photonics X, edited by Georg von Freymann, Winston V. Schoenfeld, Raymond C. Rumpf, Proceedings of SPIE Vol. 10115 (SPIE, Bellingham, WA, 2017) Seven-digit Article CID Number.

ISSN: 0277-786X

ISSN: 1996-756X (electronic)

ISBN: 9781510606715

ISBN: 9781510606722 (electronic)

Published by

SPIE

P.O. Box 10, Bellingham, Washington 98227-0010 USA

Telephone +1 3606763290 (Pacific Time) · Fax +1 3606471445

SPIE.org

Copyright (C) 2017, Society of Photo-Optical Instrumentation Engineers.

Copying of material in this book for internal or personal use, or for the internal or personal use of specific clients, beyond the fair use provisions granted by the U.S. Copyright Law is authorized by SPIE subject to payment of copying fees. The Transactional Reporting Service base fee for this volume is $\$ 18.00$ per article (or portion thereof), which should be paid directly to the Copyright Clearance Center (CCC), 222 Rosewood Drive, Danvers, MA 01923. Payment may also be made electronically through CCC Online at copyright.com. Other copying for republication, resale, advertising or promotion, or any form of systematic or multiple reproduction of any material in this book is prohibited except with permission in writing from the publisher. The CCC fee code is $0277-786 \mathrm{X} / 17 / \$ 18.00$.

Printed in the United States of America.

Publication of record for individual papers is online in the SPIE Digital Library.

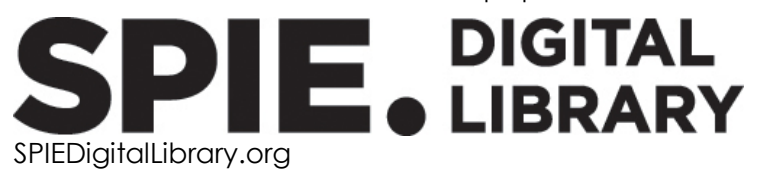

Paper Numbering: Proceedings of SPIE follow an e-First publication model. A unique citation identifier (CID) number is assigned to each article at the time of publication. Utilization of CIDs allows articles to be fully citable as soon as they are published online, and connects the same identifier to all online and print versions of the publication. SPIE uses a seven-digit CID article numbering system structured as follows:

- The five digits correspond to the SPIE volume number.

- The last two digits indicate publication order within the volume using a Base 36 numbering system employing both numerals and letters. These two-number sets start with $00,01,02,03,04$, 05, 06, 07, 08, 09, OA, OB ... OZ, followed by 10-1Z, 20-2Z, etc. The CID Number appears on each page of the manuscript. 


\title{
Contents
}

\author{
vii Authors \\ ix Conference Committee
}

\section{LARGE AREA FABRICATION}

1011502 Interference and nanoimprint lithography for the patterning of large areas (Invited Paper) [10115-1]

1011503 Manufacturing of polymer optical waveguides using self-assembly effect on preconditioned 3D-thermoformed flexible substrates [10115-2]

1011504 Partial etch phase (PEP) optical elements for high-volume applications [10115-3]

\section{NANOPLASMONICS I}

1011508 Integration of 3D printed lens with InGaN light-emitting diodes with enhanced light extraction efficiency [10115-8]

1011509 LOPA-based direct laser writing of multi-dimensional and multi-functional photonic submicrostructures [10115-9]

\section{NANOPLASMONICS II}

$10115 \mathrm{OB}$ Control of spectral transmission enhancement properties of random anti-reflecting surface structures fabricated using gold masking [10115-11]

\section{NANOPLASMONICS III}

10115 OD Optical fiber plasmonic lens for near-field focusing fabricated through focused ion beam [10115-14]

$10115 \mathrm{OE}$ Metal free structural colours via disordered nanostructures with $\mathbf{n m}$ resolution and full CYMK colour spectrum [10115-15]

ADVANCED FABRICATION WITH DMD AND SLM DEVICES: JOINT SESSION WITH CONFERENCES 10115 AND 10117

10115 OK Laser-assisted dealloying for direct-write patterning of plasmonic nanostructures [10115-22] 
DIRECT LASER WRITING FOR BIOLOGICAL AND MEDICAL APPLICATIONS: JOINT SESSION WITH CONFERENCES 10115 AND 10095

$10115 \mathrm{OL}$ Multi-photon microfabrication of three-dimensional capillary-scale vascular networks (Invited Paper) [10115-23]

10115 ON Process development for high-resolution 3D-printing of bioresorbable vascular stents (Best Student Paper Award) [10115-25]

10115 OP Nanostencil lithography with scanning optical fiber tip [10115-27]

3D LASER LITHOGRAPHY FOR PRODUCTION: JOINT SESSION WITH CONFERENCES 10115 AND 10095

$101150 Q \quad$ Two-photon polymerization as a structuring technology in production: future or fiction? (Invited Paper, Best Paper Award) [101 15-28]

10115 OR Progress in fabrication of waveguide spatial light modulators via femtosecond laser micromachining [10115-29]

10115 OS Strategies for rapid and reliable fabrication of microoptical structures using two-photon polymerization [10115-30]

$101150 \mathrm{U} \quad$ Novel seamless origination and tooling approaches for film imprinting technologies [101 15-32]

\section{D LASER LITHOGRAPHY: JOINT SESSION WITH CONFERENCES 10115 AND 10095}

$101150 \mathrm{~V}$ Laser subtractive-additive-welding microfabrication for Lab-On-Chip (LOC) applications (Invited Paper) [10115-33]

10115 OW Direct-laser metal writing of surface acoustic wave transducers for integrated-optic spatial light modulators in lithium niobate [10115-34]

10115 OX Realisation of 3D metamaterial perfect absorber structures by direct laser writing [10115-35]

$101150 Z \quad$ Nanostructures for highly efficient infrared detection [10115-37]

1011510 Nonlinear polymer/quantum dots nanocomposite for two-photon nanolithography of photonic devices [10115-38]

\section{POSTER SESSION}

1011511 Laser nanolithography and pyrolysis of SZ2080 hybrid for slowing light in 3D photonic crystals [10115-39]

1011512 Fabrication of electro-wetting liquid lenticular lens by using diffuser [10115-40] 
$1011513 \mathrm{Ta}_{2} \mathrm{O}_{5} / \mathrm{Al}_{2} \mathrm{O}_{3} / \mathrm{SiO}_{2}$ - antireflective coating for non-planar optical surfaces by atomic layer deposition [10115-41]

1011514 Bioresists from renewable resources as sustainable photoresins for 3D laser microlithography: material synthesis, cross-linking rate and characterization of the structures [10115-42]

1011515 Two-stage evaporated ordered nanoporous ultrathin metal films using reusable template [10115-43]

1011518 Holographic fabrication of hole arrays in AZO for study of surface plasmon resonances [10115-46]

1011519 Reliability and manufacturability of 25G VCSELs with oxide apertures formed by in-situ monitoring [10115-47]

101151 A Quantum dot based 3D photonic devices [10115-48] 
Proc. of SPIE Vol. 10115 1011501-6 Downloaded From: https://www.spiedigitallibrary.org/conference-proceedings-of-spie on 25 Apr 2023
Terms of Use: https://www.spiedigitallibrary.org/terms-of-use 


\section{Authors}

Numbers in the index correspond to the last two digits of the seven-digit citation identifier (CID) article numbering system used in Proceedings of SPIE. The first five digits reflect the volume number. Base 36 numbering is employed for the last two digits and indicates the order of articles within the volume. Numbers start with $00,01,02,03,04,05,06,07,08,09,0 A, 0 B \ldots . .0 Z$, followed by 10-1Z, 20-2Z, etc.

Abrashitova, Ksenia A., 10

Adewole, Murthada, 18

Aggarwal, Ishwar D., OB

Ameer, Guillermo, ON

Baker, Evan, ON

Bessonov, Vladimir O., 10

Bläsi, Benedikt, 02

Boerner, Volkmar, oU

Bonifazi, Marcella, OE

Bove, V. Michael, OR, OW

Buivydas, Ričardas, OV

Busse, Lynda E., OB

Butkus, Simas, OV

Chizhov, Artem S., 10

Cormier, Denis, 08

Cui, Jingbiao, 18

Dahlem, Marcus S., OD

Datta, Bianca C., OR, OW

Ding, Jun, 18

Domann, Gerhard, OS

Ezhov, Alexander A., 10

Fanyaeu, I., OX

Farsari, Maria, 1A

Farsheed, Adam C., ON

Fedyanin, Andrey A., 10

Flores, Raquel, OP

Franke, Jörg, 03

Frantz, Jesse A., OB

Fratalocchi, Andrea, OE

Gadonas, Roaldas, OV, 11

Gailevicius, Darius, 0Z, 11

Gandhi, Shaunak, 08

George, David, 18

Gershenfeld, Neil, OR

Gray, David, 1A

Grigalevičiūtè, Giedrè, 14

Gulkin, Dmitry N., 10

Hannigan, J. M., 04

Harnisch, Emely Marie, $0 Q$

Hartensveld, Matthew, 08

Hassan, Safaa, 18

Hasselmann, Sebastian, OS

Hauser, Hubert, 02

Hayran, Zeki, OZ, 11

Hoffmann, Gerd-Albert, 03

Höhn, Oliver, 02

Humbach, Oliver, OU

Huong, Au Thi, 09

lazikov, D., 04
Janeiro, Ricardo, OP

Jolly, Sundeep, OR, OW

Jonušauskas, Linas, OV, 11, 14

Juodkazis, Saulius, OV, 0Z, 11

Kabouraki, Elmina, 1A

Karydis, Thrasyvoulos, OR

Kašètaitè, Sigita, 14

Kim, Cheoljoong, 12

Kim, Junoh, 12

Kokareva, Natalia G., 10

Koo, Gyo Hyun, 12

Kübler, Volker, 02

Kurt, Hamza, 0Z, 11

Kyi, Wilson, 19

Lai, Ngoc Diep, 09

Lee, Junsik, 12

$\mathrm{Li}$, Jingting, OK

Li, Li, 18

Li, Zeping, 15

Lin, Yuankun, 18

Liu, Cheng, 08

Liu, Man-Chi, OL

Lott, James A., 19

Lowell, David, 18

Malinauskas, Mangirdas, OV, 0Z, 11, 14

Mao, Fei, 09

Mazur, Eric, OR, OW

Mazzone, Valerio, $\mathrm{OE}$

Mei, Lihong, 15

Melkonyan, Henrik, OD

Mick, Jörg, OU

Mizeikis, Vygantas, OX, OZ, 11

Moebius, Michael, OR, OW

Moreira, Paulo, OD

Mossberg, T. W., 04

Mück, Philip, OU

Müller, Claas, 02

Nguyen, Dam Thuy Trang, 09

Odessey, Rache, 09

Ooi, Yu Kee, 08

Ostrauskaité, Jolita, 14

Overmeyer, Ludger, 03

Paipulas, Domas, OV

Pao, James J., 19

Peltier, Abigail, $\mathrm{OB}$

Pereira, Dionisio A., OP

Pfeiffer, K., 13

Philipose, Usha, 18

Potter, Matthew, OB 
Poutous, Menelaos K., OB

Qu, Xiaopeng, 15

Rekštyłè, Sima, OV, 14

Riaziat, Majid, 19

Ruhl, Thomas, OU

Safronov, Kirill R., 10

Sakalauskas, Danas, 11

Sakellari, loanna, 1A

Šakirzanovas, Simas, 11

Sanghera, Jasbinder S., OB

Sapkota, Gopal, OB

Saudrais, Florent, 09

Savidis, Nickolaos, OR, OW

Schmitt, Robert, $\mathrm{OQ}$

Schulz, U., 13

Shaw, L. Brandon, OB

Shih, Wei-Chuan, OK

Shin, Dooseub, 12

Sim, Jee Hoon, 12

Skliutas, Edvinas, 14

Skylar-Scott, Mark A., OL

Sloyan, Karen, OD

Staliunas, Kestutis, 0Z, 11

Steenhusen, Sönke, OS

Stöver, Christoph, OU

Sun, Cheng, ON

Suttmann, Oliver, 03

Szeghalmi, A., 13

Tong, Quang Cong, 09

Tucher, Nico, 02

Tünnermann, A., 13

Turduev, Mirbek, 0Z, 11

Ugras, Christopher, 08

Vamvakaki, Maria, $1 \mathrm{~A}$

van Lith, Robert, ON

Viegas, Jaime, OP

Ware, Henry Oliver T., ON

Wellens, Christine, 02

Wolfer, Tim, 03

Won, Yong Hyub, 12

Wu, Ta-Chung, 19

Wu, Yuelong, OL

$\mathrm{XU}$, Zhimou, 15

Yanik, Mehmet Fatih, OL

Zeitler, Jochen, 03

Zhang, Hualiang, 18

Zhang, Jing, 08

Zhao, Fusheng, OK 


\title{
Conference Committee
}

\author{
Symposium Chairs
}

Jean-Emmanuel Broquin, IMEP-LAHC (France)

Shibin Jiang, AdValue Photonics, Inc. (United States)

Symposium Co-chairs

Connie J. Chang-Hasnain, University of California, Berkeley (United States)

Graham T. Reed, Optoelectronics Research Centre, University of Southampton (United Kingdom)

Program Track Chairs

Holger Becker, microfluidic ChipShop GmbH (Germany)

Winston V. Schoenfeld, CREOL, The College of Optics and Photonics, University of Central Florida (United States)

Conference Chairs

Georg von Freymann, Technische Universität Kaiserslautern (Germany)

Winston V. Schoenfeld, CREOL, The College of Optics and Photonics, University of Central Florida (United States)

Raymond C. Rumpf, The University of Texas at El Paso (United States)

\section{Conference Program Committee}

Cornelia Denz, Universität Münster (Germany)

Ruth Houbertz, Multiphoton Optics GmbH (Germany)

Saulius Juodkazis, Swinburne University of Technology (Australia)

Stephen M. Kuebler, CREOL, The College of Optics and Photonics, University of Central Florida (United States)

Akhlesh Lakhtakia, The Pennsylvania State University (United States)

Robert R. McLeod, University of Colorado at Boulder (United States)

Hernán R. Míguez, Institute of Materials Science of Seville (Spain)

Dennis W. Prather, University of Delaware (United States)

Aaron J. Pung, Clemson University (United States)

John A. Rogers, University of Illinois at Urbana-Champaign

(United States)

Thomas J. Suleski, The University of North Carolina at Charlotte

(United States)

Michael Thiel, Nanoscribe GmbH (Germany) 
Sandra Wolff, Technische Universität Kaiserslautern (Germany)

Session Chairs

1 Large Area Fabrication

Ruth Houbertz, Multiphoton Optics GmbH (Germany)

2 Nanoplasmonics I

Isabelle Staude, Friedrich-Schiller-Universität Jena (Germany)

3 Nanoplasmonics II

Juan Francisco Galisteo-López, Consejo Superior de Investigaciones Científicas (Spain)

4 Nanoplasmonics III

Sandra Wolff, Technische Universität Kaiserslautern (Germany)

5 10th Anniversary Session

Georg von Freymann, Technische Universität Kaiserslautern (Germany)

6 Advanced Fabrication with DMD and SLM Devices: Joint Session with Conferences 10115 and 10117

Michael R. Douglass, Texas Instruments Inc. (United States)

Georg von Freymann, Technische Universität Kaiserslautern (Germany)

7 3D Metrology: Joint Session with Conferences 10115 and 10117

Sanjeev Kumar $\mathbf{M}$, Texas Instruments Pvt. Ltd. (India)

Alfred Jacobsen, Visitech Engineering GmbH (Germany)

8 Direct Laser Writing for Biological and Medical Applications: Joint Session with Conferences 10115 and 10095

Michael Thiel, Nanoscribe GmbH (Germany)

9 3D Laser Lithography for Production: Joint Session with Conferences 10115 and 10095

Mangirdas Malinauskas, Vilnius University (Lithuania)

10 3D Laser Lithography: Joint Session with Conferences 10115 and 10095

Yuebing Zheng, The University of Texas at Austin (United States)

Nico Tucher, Fraunhofer-Institut für Solare Energiesysteme (Germany) 